\title{
Comparative Analysis of IT Industry's Competitiveness through Enterprise Innovation between Korea and China
}

\author{
Seong Ho Yi ${ }^{1} \&$ Wan Seon Shin ${ }^{2}$ \\ ${ }^{1}$ Graduate School PhD. course, Management of Technology Department, Sung Kyun Kwan University, Korea \\ 2 Professor, Dept. of Management of Technology, Service Engineering Laboratory Sung Kyun Kwan University, \\ Korea \\ Correspondence: Seong Ho Yi, Graduate School PhD. course, Management of Technology Department, Sung Kyun \\ Kwan University, Korea. E-mail: jslee797@naver.com
}

Received: August 30, 2014

Accepted: October 1, 2014

Online Published: October 22, 2014

doi:10.5430/jms.v5n4p82

URL: http://dx.doi.org/10.5430/jms.v5n4p82

\begin{abstract}
This paper review change of IT industry export-import structure between Korea and China by use of trade related index and focuses on analyzing comparative advantage based on time-series analysis statistics data by using analysis index of trade intensity index(TII), revealed comparative advantage index(RCA), trade specialization index(TSI).

Per economic phase, both Korea-China have mutually complementary character. Based on this point of view, the purpose of this research understand both 2 country's trade structure to strengthen Korea-China economic cooperations and examine trade drawback to analyze causes which affect trade and by its improvement direction, find out way of trade expansion.

From our economic viewpoint, Northeast economic cooperations can provide opportunity for industry technological cooperations with partner China under the circumstance of accelerating competitions among industries day by day and secure stable resource supplier as well as enlargement of export market and diversification which is expected to bring significant positive effects.
\end{abstract}

Keywords: innovation, enterprise, information, intensity index, comparative advantage index

\section{Introduction}

Innovation should be expanded through bench mark about role model enterprise and it needs excellent successful innovation enterprises should be widely known.

As innovative enterprises are widely known, it can help to make their reputations and general other companies are taking advantage of them.

Organization and brevity are noted by providing multiple aspects about enterprise's innovation with composite index.

Even though survey of enterprise innovation is continuously conducted in Korea, they are provided as total statistics information not for informations of each individual enterprise.

Enterprise's R \& D investment informations based on project reports are provided for each enterprise. However, it is hard to understand only R \& D investment represents enterprise's innovation.

As Northeast Asian countries are geographically adjacent to both a Pacific Northwest coast and in case economic cooperation is strengthened, transportation and communication costs can be reduced as well as transaction costs involved in economic exchange can be minimized. Additionally, common and comprehensive cultural features could act as a sufficient condition to promote regional trade, especially in intra-industry trade, of which may contribute to the enlargement of mutual demand. In particular, both two countries among Northeast Asian countries have a lot in common and similar cultural round such as language, lifestyle practices, and customs through geographical proximity as well as a long historically exchange experiences and even in the economic aspect, the two are complementary relations. Namely, that is because Japan can provide with the capital and advanced scientific technology and Korea can provide with development experiences and advanced technology. 
Resulting in a potentially complementary characteristics between the intra- economy can be considered infinite, where the expected benefits arising from here also shall be guaranteed enough compared to any other regional economic community in the world.

In terms of our economy position, pretty much positive effects is expected that Northeastern asian economic cooperations will provide not only opportunity for industrial technology cooperations with chinese partner but also our export market enlargement and diversity with stable resources suppliers. Thus, the purpose of this research is evaluating trade structure to fortify two countries economic cooperations, analyze factor that affect trade structure to find out trade problems and to search for way of trade increase.

This paper is organized as follows; Chapter 2 explains this paper related precedent study and statistic data which are used at empirical analysis. Chapter 3 reviews structural characteristic of Korea-China steel industry taking advantage of general trade statistics. Chapter 4 decomposes and measure interrelated trade relationship by way of UN COMTRADE statistics including Trade Intensity Index, Trade Specification Index and Revealed Comparative Advantage Index. Finally, Chapter 5 summarizes analysis result of this research and gives final conclusions.

\section{Precedent Research and Statistic Data}

In order to analyze trade determinants between 2 countries, trade intensity index was used to analyze by taking advantage of Japanese Yamazawa (2010) theory--Yamazawa, I., "Intensity Analysis of World Trade Flow" Histotsubashi Journal of Economics of trade intensity.

To analyze these trade determinants, detailed factor should be identified. However, realistically, there are a lot of unidentified factors as well as its diversity which it is hard to explain specifically. So, I look into to focus on trade structure factor as a mentioned research point, namely, analysis of trade determinant. Analysis period is from 2000 to 2012. From 2000 to 2005 and 2012 are restricted for both 2 countries trade determinant analysis as recent statistical data of international statistical data are not announced or are difficult to get them. Per reviewing precedent research, Lee (2008), Lee (2012) by trade specialization index, there are analysis research for Cho (2010), Oh(2012), Oh(2013)by revealed comparative advantage index and Kim \& $\operatorname{Kim}(2011)$ by trade intensity index. The papers of Yu \& Han (2012) have differentiation compared to other papers as above mentioned all 3 indexes are used for study.

This research was done empirical analysis based on statistical data, especially, trade analysis between Korea and China are evaluated in view of objective assess. Thus, two countries' positions were reviewed as a counterpart country with a focus on South Korea. The statistical data published by international organization were mainly used. The main data were made based on Standard International Trade Classification - Revision 3, Korea Customs Office, Korea International Trade Association and mainly, UN Comtrade. The statistic data is notionally meaning as statistic about cargo exchanges between national economy and other countries. every commodities of delivered-in and delivered-out from a certain country's economic zone to increase its country's physical resources or to diminish physical resources are counted for record. The commodities that simply pass a certain country or temporarily delivered-in \& out commodity are not included into trade statistics because they are not increasing or diminishing volume of its country's physical resources data base.

\section{Present Status and Characteristic for Korea-China IT Industry}

South Korean economy should change from government-led economy to the private sector, from outward growth-oriented to the center of the development implicitly, from the economic structure of the hardware to the software-oriented economic structure, from protection and regulation to competition and autonomy as well as the enterprise activities should be also changed from focusing on the domestic market to the world market.

Today, globalization has emerged as a buzzword in the Korean society. In case we look at globalization as a aspect of corporate activities, various activities of value-added chain such as research \& development, component supply, production and marketing activities, etc are changed from domestic-oriented to world-oriented. Therefore, domestic market should be changed from one of world many markets.

Far as until now, the method type of the domestic production and overseas export including only simple overseas production strategies that aims to take advantage of poorly paid foreign labor should be changed into the optimal allocation of resources under the global level together with to pursue the optimal combination of production factors' as a globalization strategy.

These tasks must be pursued in dimension not only because Korean economy should consistently develop but also because of survival strategy that we can manage to survive at borderless unlimited competition era under the WTO era. 
Table 1. Top 10 export items in 2000

\begin{tabular}{cccccc}
\hline \multicolumn{3}{c}{} & & & \multicolumn{2}{c}{ Unit: USD1,000, Ton } \\
\hline Period & Item & HScode & $\begin{array}{c}\text { Export } \\
\text { weight }\end{array}$ & $\begin{array}{c}\text { Export } \\
\text { amount }\end{array}$ & Trade balance \\
\hline 2000 & electricity & 85 & $2,144,176$ & $46,365,814$ & $10,854,729$ \\
\hline 2000 & machinery $\cdot$ computer & 84 & $2,378,653$ & $29,732,191$ & $8,859,068$ \\
\hline 2000 & automobile & 87 & $2,778,477$ & $15,265,527$ & $13,634,266$ \\
\hline 2000 & petroleum $\cdot$ coal & 27 & $40,003,169$ & $9,375,503$ & $-28,701,630$ \\
\hline 2000 & ship & 89 & $7,216,050$ & $8,229,445$ & $8,036,911$ \\
\hline 2000 & plastic & 39 & $6,984,473$ & $7,279,677$ & $4,567,468$ \\
\hline 2000 & steel & 72 & $12,500,325$ & $5,954,688$ & $-35,487$ \\
\hline 2000 & organic compound & 29 & $8,528,903$ & $4,969,520$ & $-1,056$ \\
\hline 2000 & filament fiber & 54 & $1,006,532$ & $4,804,218$ & $4,017,919$ \\
\hline 2000 & knitting & 60 & 364,402 & $2,522,109$ & $2,426,379$ \\
\hline
\end{tabular}

Source: Own

Table 2. Top 10 export item in 2005

Unit: USD1,000, TON

\begin{tabular}{cccccc}
\hline & & & & \multicolumn{2}{c}{ Unit: USD1,000, TON } \\
\hline Period & Item & HScode & Export weight & $\begin{array}{c}\text { Export } \\
\text { amount }\end{array}$ & Trade balance \\
\hline 2005 & electricity & 85 & $2,379,539$ & $80,488,019$ & $31,754,060$ \\
\hline 2005 & $\begin{array}{c}\text { machinery } \cdot \\
\text { computer }\end{array}$ & 84 & $3,610,932$ & $38,563,249$ & $10,584,838$ \\
\hline 2005 & automobile & 87 & $5,541,103$ & $37,491,235$ & $33,298,061$ \\
\hline 2005 & coal & 89 & $7,610,949$ & $17,231,478$ & $16,094,094$ \\
\hline 2005 & petroleum - coal & 27 & $35,847,748$ & $15,709,419$ & $-51,847,050$ \\
\hline 2005 & plastic & 39 & $9,499,673$ & $14,262,514$ & $8,861,933$ \\
\hline 2005 & steel & 72 & $15,048,220$ & $12,804,737$ & $-3,555,765$ \\
\hline 2005 & optical instrument & 90 & 165,476 & $11,911,050$ & $-967,645$ \\
\hline 2005 & organic compound & 29 & $10,905,426$ & $10,539,295$ & $2,062,227$ \\
\hline 2005 & steel product & 73 & $2,483,584$ & $4,425,868$ & $1,872,647$ \\
\hline
\end{tabular}

Source: Own

Table 3. Top 10 export item in 2011

\begin{tabular}{cccccc}
\hline & & & & \multicolumn{2}{r}{ Unit: USD1,000, TON } \\
\hline Period & Item & HS Code & $\begin{array}{c}\text { Export } \\
\text { Weight }\end{array}$ & Export Amount & Trade Balance \\
\hline 2011 & electricity & 85 & $2,492,738$ & $118,542,862$ & $48,794,634$ \\
\hline 2011 & automobile & 87 & $8,011,982$ & $67,096,998$ & $57,947,004$ \\
\hline 2011 & $\begin{array}{c}\text { machinery } \\
\text { computer }\end{array}$ & 84 & $5,965,440$ & $59,658,652$ & $10,330,096$ \\
\hline 2011 & ship & 89 & $16,200,267$ & $54,133,104$ & $51,729,626$ \\
\hline
\end{tabular}




\begin{tabular}{cccccc}
\hline 2011 & petroleum $\cdot$ coal & 27 & $56,597,644$ & $53,088,429$ & $-120,586,577$ \\
\hline 2011 & optical instrument & 90 & 591,264 & $36,499,242$ & $19,450,445$ \\
\hline 2011 & plastic & 39 & $11,915,748$ & $27,719,360$ & $16,869,288$ \\
\hline 2011 & steel & 72 & $26,801,230$ & $27,581,063$ & $-857,152$ \\
\hline 2011 & organic compound & 29 & $15,332,920$ & $22,468,839$ & $7,604,440$ \\
\hline 2011 & steel product & 73 & $4,645,340$ & $11,690,016$ & $4,315,843$ \\
\hline
\end{tabular}

Source: Own

Table 4. Top 10 export item in 2013

\begin{tabular}{cccccc}
\hline & & & & \multicolumn{2}{c}{ Unit: USD1,000, TON } \\
\hline Period & Item & HS Code & Export Weight & $\begin{array}{c}\text { Export } \\
\text { Amount }\end{array}$ & Trade Balance \\
\hline 2013 & electricity & 85 & 772,794 & $41,022,310$ & $18,123,810$ \\
\hline 2013 & automobile & 87 & $2,721,168$ & $24,019,422$ & $20,799,425$ \\
\hline 2013 & $\begin{array}{c}\text { machinery } \text { • } \\
\text { computer }\end{array}$ & 84 & $1,849,268$ & $19,645,287$ & $4,471,673$ \\
\hline 2013 & petroleum - coal & 27 & $19,550,412$ & $18,647,477$ & $-44,836,514$ \\
\hline 2013 & optical instrument & 90 & 175,109 & $12,203,470$ & $6,643,405$ \\
\hline 2013 & ship & 89 & $4,525,000$ & $11,137,928$ & $10,484,861$ \\
\hline 2013 & plastic & 39 & $4,476,361$ & $10,186,121$ & $6,618,144$ \\
\hline 2013 & organic compound & 29 & $5,784,018$ & $8,707,390$ & $3,706,811$ \\
\hline 2013 & steel & 72 & $8,797,975$ & $7,569,296$ & 375,169 \\
\hline 2013 & steel product & 73 & $1,667,706$ & $3,542,638$ & 830,446 \\
\hline
\end{tabular}

Source: Own

Per reviewing Table 1, Table 2 and Korean top 10 export products against world market in 2000, steel is US\$5.95 billion as rank 7. However, in 2005, the figure is increased two times as US\$12.8billion even though it is same as rank 7. Per reviewing Table 3, even though rank is 1 grade down as rank 8, export amount is US\$27.6billion which 6 years has passed and is increased approximately more than double compared to 2005 as export is picking up. Per evaluating 2013 in Table 4, even though actual statistic data for 2/4quarters does not come out until now, we can figure out tha it is US\$7.57 which is considerably low export volumes compared to previous years. There is analysis for those reasons as follows : worldwide economy depression, medium - high-income brackets's lack of purchase, housing \& constructions fields's recession as well as long-term economic depression. Those are one of phenomenon not only happen in Korea but also appear worldwide trend. However, it is the first time to accomplish trade balance surplus as approximately US\$380million per steel sector.

Table 5. Korea's import \& export to world steel market (Unit: US\$1)

\begin{tabular}{|c|c|c|c|c|}
\hline Year & 1995 & 2000 & 2010 & 2012 \\
\hline Export & $\$ 4,719,411,712 \$$ & $\$ 5,954,687,872$ & $2 \$ 12,804,736,889 \$ 21,751,233,245$ & $\$ 25,375,016,539$ \\
\hline Import & $\$ 6,909,957,632 \$$ & $\$ 5,990,174,843$ & $3 \$ 16,360,501,925 \$ 24,870,600,948$ & $\$ 23,822,002,958$ \\
\hline $\begin{array}{c}\text { Trade } \\
\text { Balance }\end{array}$ & $-\$ 2,190,545,920$ & $-\$ 35,486,971$ & $-\$ 3,555,765,036-\$ 3,119,367,703$ & $\$ 1,553,013,581$ \\
\hline
\end{tabular}

Source: Own 
Table 6. China's import \& export to world steel market (Unit: US\$1)

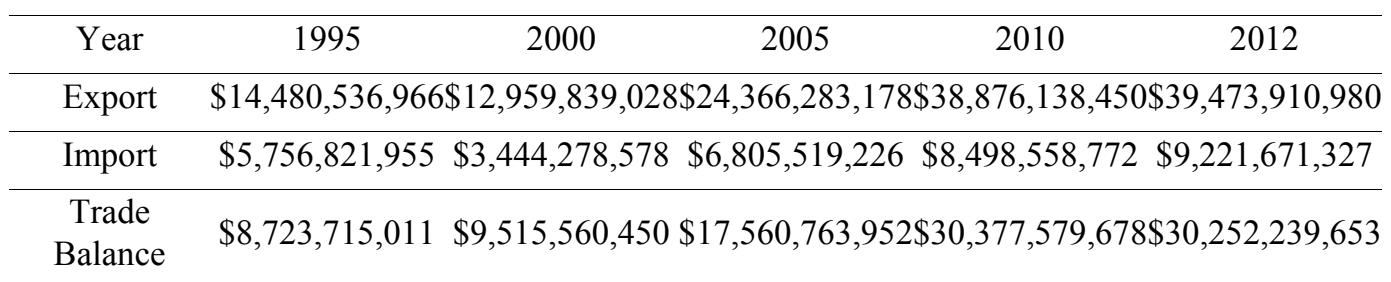

Source: Own

Table 7. Production share for Korea steel industry (Unit: Ton, \%)

\begin{tabular}{|c|c|c|c|c|c|c|}
\hline \multirow{2}{*}{ Year } & \multirow{2}{*}{1990} & \multirow{2}{*}{2000} & \multirow{2}{*}{2007} & \multirow{2}{*}{2011} & \multicolumn{2}{|c|}{ Annual Average Rate } \\
\hline & & & & & ‘90 ’00 & '00 ’10 \\
\hline World & 770,141 & 847,662 & $1,346,577$ & $1,516,794$ & 1.0 & 5.4 \\
\hline Korea & $\begin{array}{c}23,125 \\
(3.0)\end{array}$ & $\begin{array}{c}43,107 \\
(5.1)\end{array}$ & $\begin{array}{c}51,517 \\
(3.8)\end{array}$ & $\begin{array}{c}68,519 \\
(4.5)\end{array}$ & 6.4 & 4.3 \\
\hline
\end{tabular}

Source: Own

Then, let's focus on steel only and evaluate it. Analyzing above Table 5 and Table 6, we can easily find out overall persistently growing trend through trade balance of Korea's steel import \& export status during 1995-2012.

We can figure out transformation of Korean export major industry. At the beginning of last the 3rd Republic, Korean government has export strategy with labor-intensive industry such as textile, footwear, clothes industry in the name of export drive policy (It is one of typical trade policy for developing country that put pressure on export enlargement to cover up sale shrink resulting from lack of consumption due to domestic economic depression. During recession era, domestic demand is diminishing and oversupply happens. Enterprise is inclined to expand export by even cutting export price in order to prevent production rate's decrease as well as unintended inventory pileup). Then, it is changed into high value-added industry such as automobile, ship and electronic items from 1990's.

Namely, it is transferred from labor-intensive NICs industry into capital -intensive industry, of which means that it is not simply industry itself is transferred but national wealth itself is fundamentally changed to dedicate national wealth increase through economic growth.

On the other hand, per viewing Table 6 from 1995 to 2012, China's export amount is superior to that of Korea more than 3 times and trade deficit never happened at all. During 2010-2012, trade balance surplus has been persistently approximately US\$1billion and range of trade balance surplus is also increasingly expanding.

The reasons are China has been exporting steel from mid 1980's by long-term basis as a national major industry, worldwide export marketing networks are well operated as well as enterprise transfer to foreign country with foreign joint-venture investment (Overseas investment generally divided into investment to financial asset and direct investment. As Joint-venture investment is one of direct investment, it is said that enterprise is operated by jointly invested with local capital. Investment to financial asset such as loan and investment to securities is simply to get profit itself without involving enterprise management, on the other hand, direct investment is to involve enterprise management by keeping stock) that huge finance is transferring into developing country is relatively not brisk, of which is one of Japanese trade balance improvement effects in the Chinese steel industry.

\section{Structural Analysis of IT Industry between Korea-China}

\subsection{Empirical Analysis Model for Korea-China IT Industry}

In order to understand the competitiveness of the steel industry between Korea and China, It is necessary to take advantage of utilizing some of the more traditional method of analysis.

It is trade intensity index, trade specialization index and revealed comparative advantage index. 
Each measuring index for competitiveness index could be fragmentary analysis method to see only one side as well as problem is implied. However, it is helpful to see trade structure resulting from industrial competitiveness.

Trade intensity index analyze competitive relations of oversea market between 2 countries by relative trade intensity of competitiveness analysis indicator to consider coverall import absorbing power of import country, comparative advantage of export country together with bilateral or global trade flow. Trade specialization index has some problems to consider only bilateral transaction of exporting and importing countries without considering the world's total trade flows.

Revealed comparative advantage index shows realized competitiveness of export country, but, has problem that import absorbing power such as market condition of import country is not taken into account at all.

Trade is accomplished at the point that import demand of import country meets supply power of export country.

However, revealed comparative advantage index has disadvantage that only the relative export proportion of the exporting country is considered.

We can examine specific calculation method as well as index derived from mentioned calculation. Trade intensity in dex presented by I.Yamazawa shows exporting country's export comparative market intensity against importing cou ntry. Thus, trade intensity index can be defined as follows;

Economic meaning of trade intensity is if I country's export proportion against $\mathrm{j}$ country is bigger or $\mathrm{j}$ country's import ratio against world total import is smaller, this index is going up.

$$
\begin{aligned}
I_{i j}=\frac{\left(X_{i j} / M_{j \omega}\right)}{\left(X_{i \omega} / M_{\omega \omega}\right)} & \\
I_{i j} & =I \text { country's trade intensity against } j \text { country } \\
X_{i \omega} & =\text { Icountry's total export } \\
M_{j \omega} & =j \text { country's total import } \\
M_{\omega \omega} & =\text { World total import }(=\text { Total export })
\end{aligned}
$$

In case $\mathrm{j}$ country export ratio among I country's total export is $1 \%$ and $\mathrm{j}$ country import is $1 \%$ against world total import, this index is 1 . Therefore, formular $<1>$ can be changed into formular $<1^{\prime}>$ as follows

$$
I_{i j}=\frac{\left(X_{i j} / X_{i \omega}\right)}{\left(M_{i \omega} / M_{\omega \omega}\right)}------------(1)^{\prime}
$$

Numerator of formular (1)' shows I country's share against $\mathrm{j}$ country's market and denominator of formular (1)' shows I country's world market share.

Namely, this index means I country's world market share against $\mathrm{j}$ country's market share, of which it calls comparative market intensity.

Additionally, to make in-depth analysis about Korea-Japan complementary relationship, we can measure trade specia lization degree through qualitative rather than quantitative indicators.

$<$ Formular $>$

$$
T S I=\frac{X_{i}-M_{i}}{X_{i}+M_{i}}
$$

(Xi: Export of certain industry, Mi: Import of certain industry)

As Trade specialization index (TSI) is between maximum value +1 and minimum value -1 , if mentioned index is bigger, it means the competitiveness is strong. If it is o, export amount equals to import amount which means the active intra-industry trade is done in reality. In case it comes closer into -1 from 0 , it means degree of import specialization is high and if it comes closer into +1 from 0 , it means degree of export specialization is high. Further more, if TSI is +1 , it is perfect export specialization, on the contrary, if TSI is -1 , it is perfect import specialization. As it is indicator of relative comparative advantage in the export, it is another indicator to analyze between the two countries or in the world for a particular market. TSI is available to analyze by item, by country at a certain point including time series comparision at the same time which is useful to explain bilateral trade or labor segregation 
structure.

Revealed Comparative Advantage index (RCA) is the most widely used index to express export competitiveness of certain goods.

If a certain country exports a particular product of revealed comparative advantage index to other countries some extent large volume product rather than other countries, it is based on assumption that this country has export competitiveness.

RCA index has merit to compare competitiveness between countries that have different economic scale easily.

If RCA index is bigger than 1 , it means this product has comparative advantage rather than other products in his own country.

Revealed Comparative Advantage (RCA) index suggested by Balassa (1991) can be calculated as following formular.

$<$ Formular $>\mathrm{RCAi}=\frac{E X_{i} / W E X_{i}}{T E X / T W E X} \times 100$

EXi: i industry's export amount from a certain country.

WEXi: i industry's export amount against world market.

TEX: a certain country's total export amount.

TWEX: export amount of total products against world.

In case RCA index is smaller than 1 , it means this product has comparative disadvantage rather than other products in his own country.

At first, RCA index is suggested as alternative comparative advantage calculation method under the realistic conditio $\mathrm{n}$ of availability to get relative production cost or relative price data.

Consequently, it is used comprehensive indicator of comparative advantage possibility according to relative price shift caused by technical factors, factor endowments difference as it shows comparative accomplishments without attributable to a particular theory of comparative advantage as well as including market share coming from economic scale and possibility of trade shift.

By using above 3 comparative index of competitiveness, let me analyze competitiveness of Korea-China steel industr $\mathrm{y}$ at next chapter.

4.2 Empirical Analysis Result for Korea-China IT Industry

4.2.1 Revealed Comparative Advantage Index for Korea-China IT Industry

Now, specifically, let's calculate RCA index for Korea-China Steel Industry as follows;

Table 8. Korean Steel export amount to China

\begin{tabular}{cccccc}
\hline Period & Trade Flow & Reporter & Partner & Code & Trade Value \\
\hline 2000 & Export & Korea & China & 72 & $\$ 1,163,132,347$ \\
\hline 2005 & Export & Korea & China & 72 & $\$ 2,172,865,661$ \\
\hline 2012 & Export & Korea & China & 72 & $\$ 3,489,370,673$ \\
\hline
\end{tabular}

Source: Own

Table 9. World total steel export amount

\begin{tabular}{cccccc}
\hline \multirow{2}{*}{ Period } & $\begin{array}{l}\text { Trade } \\
\text { Flow }\end{array}$ & Reporter & Partner & Code & Trade Value \\
\hline 2000 & Export & world & world & 72 & $\$ 119,516,784,203$ \\
\hline 2005 & Export & world & world & 72 & $\$ 280,871,900,005$ \\
\hline 2012 & Export & world & world & 72 & $\$ 385,020,864,554$ \\
\hline
\end{tabular}

Source: Own 
Table 10. Korean total export amount to China

\begin{tabular}{cccccc}
\hline Period & Trade Flow & Reporter & Partner & Code & Trade Value \\
\hline 2000 & Export & Korea & China & Total & $\$ 20,466,015,819$ \\
\hline 2005 & Export & Korea & China & Total & $\$ 24,027,420,422$ \\
\hline 2012 & Export & Korea & China & Total & $\$ 38,795,945,824$ \\
\hline
\end{tabular}

Source: Own

$$
\text { Wn }
$$

Table 11. World total commodity export amount

\begin{tabular}{cccccc}
\hline Period & Trade Flow & Reporter & Partner & Code & Trade Value \\
\hline 2000 & Export & world & world & total & $\$ 6,338,632,926,696$ \\
\hline 2005 & Export & world & world & total & $\$ 10,361,240,970,216$ \\
\hline 2012 & Export & world & world & total & $\$ 15,117,806,098,405$ \\
\hline
\end{tabular}

Source: Own

Table 12. RCA Index for Korea-China steel industry

\begin{tabular}{lrrrc}
\hline Year & $\begin{array}{l}\text { (1)Korean } \\
\text { Export } \\
\text { China/World } \\
\text { Steel Export }\end{array}$ & $\begin{array}{r}\text { Steel } \\
\text { against } \\
\text { Total }\end{array}$ & $\begin{array}{l}\text { (2)Korean } \\
\text { Export } \\
\text { China/World } \\
\text { Commodity Export } \\
\text { Cogainst }\end{array}$ & $\begin{array}{c}\text { Total } \\
\text { Total }\end{array}$ \\
\hline 2000 & 0.010 & 0.003 & 3.333 \\
\hline 2005 & 0.008 & 0.002 & 4.000 \\
\hline 2012 & 0.009 & 0.003 & 3.000 \\
\hline
\end{tabular}

Source: Own

As we can understand above table, if a certain industry's RCA index is bigger than 1, it means it has comparative advantage rather than other industries or if it is less than 1, it has disadvantage rather than other industries. Therefore, the calculated RCA index of 2000 is 3.333 which means that Korean steel industry has comparative advantage rather than other industries against China. As the calculated RCA index of 2005 is 4.000 and of 2012 is 3.000 respectively, when we evaluate them through time serial analysis, Korean steel industry has high comparative advantage against that of China for more than 10 years from 2000 and we can figure out its comparative advantage degree is getting higher.

\subsubsection{Trade Specialization Index for Korea-China IT Industry}

As TSI is between maximum value +1 and minimum value -1 , if mentioned index is bigger, it means the competitiveness is strong. If it is o, export amount equals to import amount. In case it comes closer into -1 , it means degree of import specialization is high and if it comes closer into +1 , it means degree of export specialization is high. As it is relative comparative advantage index in export, it is index for analyzing bilateral or against world market competitiveness. Therefore, per reviewing Table 15, even though Korean steel export volume against China has been increasing more than US\$1billion every 5 years through time-serial analysis method from 2000 to 2012, Japan steel export volume against Korea also has been increasing more than US\$3billion(namely, over 3 times rather than Korea) every 5 years. As specialization index is closer to -1 based on standard 0 , Korea has import specialization degree is high, on the other hand, per Table 16, even though China has same figures, however, all of its figures are the plus $(+)$ marks, namely, as it is closer to +1 , we can understand export specialization degree is high. 
Table 13. Korea steel export amount to China

\begin{tabular}{cccccc}
\hline Period & Trade flow & Reporter & Partner & Code & Trade value \\
\hline 2000 & Export & Rep.of Korea & China & 72 & $\$ 1,163,132,347$ \\
\hline 2005 & Export & Rep.of Korea & China & 72 & $\$ 2,172,865,661$ \\
\hline 2012 & Export & Rep.of Korea & China & 72 & $\$ 3,489,370,673$ \\
\hline
\end{tabular}

Source: Own

Table 14. Chinese steel export amount to Korea

\begin{tabular}{cccccc}
\hline Period & Trade flow & Reporter & Partner & Code & Trade value \\
\hline 2000 & Export & China & $\begin{array}{l}\text { Rep.of } \\
\text { Korea }\end{array}$ & 72 & $\$ 2,493,881,388$ \\
\hline 2005 & Export & China & $\begin{array}{l}\text { Rep.of } \\
\text { Korea }\end{array}$ & 72 & $\$ 5,971,284,600$ \\
\hline 2012 & Export & China & $\begin{array}{l}\text { Rep.of } \\
\text { Korea }\end{array}$ & 72 & $\$ 8,893,926,170$ \\
\hline
\end{tabular}

Source: Own

Table 15. Korea specialization index to Japan

\begin{tabular}{ccccc}
\hline & (1)Korea & Steel Export(2) Korea & Steel Export & \\
Year & $\begin{array}{l}\text { Amount to China -Amount to China }+ \\
\text { Chinese Steel ExportChinese Steel Export } \\
\text { Amount to Korea }\end{array}$ & Amount to Korea & \\
\hline 2000 & $-\$ 1,330,749,041$ & $\$ 3,657,013,735$ & -0.364 \\
\hline 2005 & $-\$ 3,798,418,939$ & $\$ 8,144,150,261$ & -0.466 \\
\hline 2012 & $-\$ 5,404,555,497$ & $\$ 12,383,296,843$ & -0.436 \\
\hline
\end{tabular}

Source: Own

Table 16. China specialization index to Korea

\begin{tabular}{llcl}
\hline \multicolumn{5}{c}{ (1) Chinese Steel Export(2) } & Chinese Steel Export & \\
Year & $\begin{array}{l}\text { Amount to Korea -Amount to Korea }+ \\
\text { Korea Steel ExportKorea Steel Export } \\
\text { Amount to China }\end{array}$ & TSI ( = (1)/(2) ) \\
\hline 2000 & $\$ 1,330,749,041$ & $\$ 3,657,013,735$ & +0.364 \\
\hline 2005 & $\$ 3,798,418,939$ & $\$ 8,144,150,261$ & +0.466 \\
\hline 2012 & $\$ 5,404,555,497$ & $\$ 12,383,296,843$ & +0.436
\end{tabular}

Source: Own

4.2.3 Trade Intensity Index for Korea-China Industrial Structure

According to traditional trade theories, they assume that international trade is done between 2 countries and inevitably existing geographical and institutional barriers such as transportation cost, customs duty does not exist. Under these assumption, international trade is decided through price discrepancy. Traditional theories explain reason 
of this price discrepancy is difference of each country's production condition. However, real life that lots of countries are existing has factors (transportation cost, customs duty) that affect price as well as non-price factors(cultural homogeneity and historical background) that also affect trade flow.

Thus, trade flow of real life is affected by non-comparative advantage factors. It is trade intensity analysis to explain trade flow under lots of countries are existing. Trade intensity analysis has assumption that trade flow is affected by both each country's comparative advantage structure and non-comparative advantage factor. Therefore, trade flow's decisive factor is explained by comparing both ex-ante total import \& export volume and ex-post total import \& export volume. Namely, trade intensity analysis is analysis for bilateral trade flow by contrasting ratio between domestic country and partner in the world trade, shift between partner's import product's structure and domestic export product's structure.

Per reviewing trade intensity index of 2000 in Table 20, TII is 2.077 which means Korea export ratio against China is high. In 2005 and 2011, it shows 1.741 and 1.438 which means Korea export ratio against China is diminishing gradually. Per Table 21, indexes are 0.118, 0.084 and 0.071 in 2000, 2005 and 2011 respectively which means they show Korea market share against China in each year. Additionally, indexes are 0.058, 0.048 and 0.048 in 2000, 2005 and 2011 which means they show Korea's market share against world market. In other words, these indexes means Korea's world market share/China's market share which call it as relative market intensity degree.

Table 17. Korea export volume to China

Source: Own Source: Own

\begin{tabular}{cc}
\hline Year & Export Amount \\
\hline 2000 & $\$ 20,466,015,819$ \\
\hline 2005 & $\$ 24,027,420,422$ \\
\hline 2012 & $\$ 39,679,479,988$ \\
\hline
\end{tabular}

Table 18. Korea total export volume

\begin{tabular}{cc}
\hline Year & Export Amount \\
\hline 2000 & $\$ 172,267,495,379$ \\
\hline 2005 & $\$ 284,418,167,174$ \\
\hline 2012 & $\$ 555,208,897,965$ \\
\hline
\end{tabular}

Source: Own Source: Own

Table 19. China total import volume

Source: Own Source: Own

\begin{tabular}{cc}
\hline Year & Import Amount \\
\hline 2000 & $\$ 379,708,376,255$ \\
\hline 2005 & $\$ 515,866,387,675$ \\
\hline 2012 & $\$ 855,380,474,182$ \\
\hline
\end{tabular}


Table 20. World total import (export)

Source: Own Source: Own

\begin{tabular}{cc}
\hline Year & Import Amount \\
\hline 2000 & $\$ 6,513,243,011,103$ \\
\hline 2005 & $\$ 10,573,099,053,017$ \\
\hline 2012 & $\$ 17,497,143,917,260$ \\
\hline
\end{tabular}

Table 21. Korea-China trade intensity index------(1)

(1)Korea Export Amount to $\begin{aligned} & \text { (2) Korea Total Export } \\ & \text { Amount/World Total } \\ & \text { Year }\end{aligned}$
$\begin{aligned} & \text { China/China Total Import Export } \\ & \text { Amount }\end{aligned}$

\begin{tabular}{llll}
\hline 2000 & 0.054 & 0.026 & 2.077 \\
\hline 2005 & 0.047 & 0.027 & 1.741 \\
\hline 2012 & 0.046 & 0.032 & 1.438 \\
\hline
\end{tabular}

Source: Own

Table 22. Korea- China trade intensity index------(1)

\begin{tabular}{cccc}
\hline Year & $\begin{array}{c}\text { (1) Korea Export Amount to } \\
\text { China / Korea Total Export } \\
\text { Amount }\end{array}$ & $\begin{array}{c}\text { (2) China Total Import } \\
\text { Amount/World Total } \\
\text { Import }\end{array}$ & TII ( = (1)/(2) $)$ \\
\hline 2000 & 0.119 & 0.058 & 2.052 \\
\hline 2005 & 0.084 & 0.049 & 1.714 \\
\hline 2012 & 0.071 & 0.049 & 1.449
\end{tabular}

Source: Own

\section{Conclusions}

Enterprise's innovation means national innovative capability is concentrated as well as its accomplishments. However, information containing brevity, organization, durability are not given in Korea. The way of summarizing information through index in a flood of information is conducted widely.

As enterprise's innovation is complex information containing multiple aspects. This information can be provided efficiently after they are systematically aggregated.

Composite index is providing detailed index that is organized into composite index at the same time, of which supply calculation basis of composite index including related information profoundly, which can be possible to conduct multiple analysis.

In terms of industry in Korea, downstream industry of electricity and electronic engineering, auto lead innovation which results in development of rear industry such as chemistry, metal/machinery equipment. However, they are still falling short of.

This paper is mainly different from the former studies because I use 3 tools, namely, trade intensity index, trade specialization index and revealed comparative advantage index. Usually, former studies are used only 1 or 2 of above tools. But, this paper use 3 tools that is unique and big advantage against other former papers.

This study empirically analyze how Korea-Sino trade dependent relationship is shifted during over 10 years(2000, $2005,2012)$ through trade intensity index, trade specialization index and revealed comparative advantage index after 
enterprise's innovation. By this, we can review import \& export structural factor of 2 countries. Let me summarize results from empirical analysis as follows;

First, trade intensity of Korea-Sino IT industry is 2.077 in 2000 which means Korea's export ratio against China is significantly high.

1.741 in 2005 and 1.438 in 2012 show that Korea's export ratio against China is going up sharply and then, it is diminishing gradually.

0.119 in 2000, 0.084 in 2005 and in 0.0712012 indicate Korea's share against China market in each year. 0.058 in 2000, 0.049 in 2005 and 0.049 in 2012 show Korea's share against world market. In other words, this index calls comparative market intensity degree which means Korea's world market share against China market share.

Second, trade specialization index (TSI) for Korea-China IT Industry is 0.364 in 2000, 0.466 in 2005 and 0.436 in 2012 respectively that the index is closer into +1 since 2000 and it is a little bit far away from +1 in 2012 . As TSI is between maximum value +1 and minimum value -1 , if mentioned index is bigger, it means the competitiveness is strong. If it is o, export amount equals to import amount. In case it comes closer into -1 , it means degree of import specialization is high and if it comes closer into +1 , it means degree of export specialization is high. Therefore, Korea is comparative advantage of export specialization and China is comparative advantage of import specialization.

Third, RCA index is 3.333 in 2000 . As that is significantly shorter than 1, Korean IT industry is considerably comparative advantage with China compared to other industries. RCA index is 4.000 in 2005 and 3.000 in 2012 which shows it is pretty much improved rather than 2000, however, it is diminishing after 2005 and even it is still much higher than 1 means that Korea is comparative advantage against China compared to other industries.

\section{References}

Balassa. (1991). A note on Balassa's hypothesis. Atlantic Economic Journal, 19(1), 197-232

Kim, Dong-Ho, \& Youn, Myoung-Kil. (2012). Distribution Knowledge, Research, and Journal in Korea. Journal of Distribution Science, 10(10), 5-9.

Lee, Hong-Bae. (2007). Analysis on Structural Factors about Trade Imbalance Status among Korea, Japan and China. Korea-Japan Economy \& Commerce Review, 37(2), 65-72.

Lee, Hong-Bae. (2012). Production Network Change and Character between Korean and Japanese Industries. Korea-Japan Economy \& Commerce Review, 3, 25-29.

Oh, Dong-Yun. (2012). Analysis on intermediary goods' manufacturing technology structure and trade dependence relationship between Korea and China. Research on North East Asian Economy, 24(3), 85-93.

Song, Young-Uk. (2009). Influence that Korean Japanese origin image make Chinese consumer's brand character and purchase intention. Research on Industrial Economy, 22(5), 2512-2522.

Uncomtrade. (2012). 2012 Annual Statistics Reports, NewYork, USA. Retrieved from http://comtrade.un.org/db/dqQuickQuery.aspx

WTO. (2012). 2012 Annual Statistics Reports, NewYork, USA. Retrieved from http://www.wto.org/english/res_e/statis_e/its2013_e/its13

Yamazawa, I. (2010). Intensity Analysis of World Trade Flow. Histotsubashi Journal of Economics, 2, 212-221

Youn, Myoung-Kil, \& Kim, Yu-Oh. (2010). Principles of Distribution. Seoul, Korea: Doonam Publishing.

Yu, Jun, \& Han, Gi-Jo. (2012). A Study on Trade Structure of Steel Industry between China and Japan. Journal of Economy \& Commerce, 56(0), 111-127. 